\title{
JUAL BELI OBAT YANG MENGANDUNG ZAT ADIKTIF DAN NARKOTIKA PRESPEKTIF HUKUM EKONOMI SYARIAH
}

\author{
1*Rizka Batara Siregar, 2Muhammad Iqbal Fasa \\ Universitas Islam Negeri Raden Intan Lampung \\ *rizkybatara232@gmail.com
}

\begin{abstract}
Abstrak
Narkotika secara etimologi berasal dari kata Narcoticum yang berarti obat bius. Disebutkan bahwa narkotika merupakan zat atau obat yang berasal dari tanaman bukan tanaman, baik sintesis maupun semi sintesis yang dapat menyebabkan penurunan atau perubahan, hilangnya rasa nyeri, dan dapat menimbulkan ketergantungan. Dalam Hukum Positif Indonesia, Penggunaan narkotika diatur dalam Undang-Undang Nomor 35 Tahun 2009, yaitu untuk pelayanan kesehatan dan pengembangan ilmu pengetahuan. Sedangkan dalam Hukum Islam, narkotika dianalogikan sebagai khamr karena mempunyai illat yang sama dengan khamr yaitu dapat merusak akal dan memabukkan yang haram hukumnya apabila dikonsumsi. Dari kedua sumber dasar hukum tersebut, bagaimana hukum penggunaan narkotika dalam hukum Positif Indonesia dan hukum Islam serta bagaimana komparasi tentang narkotika dalam Hukum Positif Indonesia dan Hukum Islam.

Penelitian ini merupakan jenis penelitian kepustakaan (library research), yaitu penulis mencoba mengumpulkan data dan informasi yang bersumber dari data-data kepustakaan seperti buku, jurnal, kitab, dan artikel. Dalam penelitian ini penulis membahas jual beli obat yang mengandung zat adiktif dan narkotika prespektif hukum ekonomi syariah.

Penelitian ini menunjukan bahwa jual beli obat yang mengandung zat adiktif dan narkotika dewasa ini masih diperbolehkan sebagai sarana pengobatan dan penelitian. penggunaan narkotika untuk pengobatan dalam Hukum Islam memberikan keringanan (rukhsah) dengan adanya kaidah tentang keadaan darurat, yaitu sesuatu yang haram boleh dikonsumsi akan tetapi harus memenuhi syarat-syarat dari keadaan darurat.
\end{abstract}

Kata Kunci: Jual Beli Obat, Zat Adiktif, Hukum Islam, Maqashid Syariah

\begin{abstract}
Narcotics etymologically comes from the word Narcoticum which means an anesthetic. It is stated that narcotics are substances or drugs derived from non-plant plants, both synthetic and semi-synthetic which can cause a decrease or change, loss of pain, and can cause dependence. In Indonesia's Positive Law, the use of narcotics is regulated in Law Number 35 of 2009, namely for health services and scientific development. Whereas in Islamic law, narcotics are analogous to khamr because they have the same illat as khamr, which can damage the mind and intoxicate which is forbidden when consumed. From the two sources of legal basis, how is the law on the use of narcotics in Positive Indonesian law and Islamic law and how is the comparison of narcotics in Indonesian Positive Law and Islamic Law.

This research is a type of library research, where the author tries to collect data and information sourced from library data such as books, journals, books, and articles. In this study, the author discusses the sale and purchase of drugs containing addictive substances and narcotics from the perspective of sharia economic law.

This study shows that the sale and purchase of drugs containing addictive substances and narcotics is still allowed as a means of treatment and research. The use of narcotics for treatment in Islamic law provides relief (rukhsah) with the existence of rules regarding emergencies, namely something that is forbidden to be consumed but must meet the requirements of an emergency.
\end{abstract}

Keywords: Selling and Buying Drugs, Addictive Substances, Islamic Law, Maqashid Syariah

\section{PENDAHULUAN}

Penyalahgunaan dan penggunaan Narkoba untuk layanan kesehatan telah meluas ke seluruh wilayah Indonesia. Narkoba merupakan singkatan dari narkotika, psikotropika, dan obat-obatan terlarang. Kemudian ada istilah lain yakni NAPZA yang berasal dari narkotika, psikotropika, dan zat adiktif. Istilah-istilah tersebut mengacu pada kelompok senyawa yang umumnya memiliki risiko kecanduan bagi penggunanya. 
Terdapat penyalahgunaan narkotika. Bila narkotika digunakan secara terus menerus atau melebihi takaran yang telah ditentukan akan mengakibatkan ketergantungan. Ketergantungan inilah yang akan mengakibatkan gangguan fisik dan psikologis, karena terjadinya kerusakan pada sistem syaraf pusat (SSP) dan organorgan tubuh seperti jantung, paru-paru, hati dan ginjal. Dampak penyalahgunaan narkotika pada seseorang sangat tergantung pada jenis narkotika yang dipakai, kepribadian pemakai dan situasi atau kondisi pemakai. Secara umum, dampak kecanduan narkotika dapat terlihat pada fisik, psikis maupun sosial seseorang.( Esther,dkk, 2021)

Pada orde yang lebih mutakhir dan modern ini, minuman keras dan hal-hal yang memabukkan bisa dianalogikan sebagai jenis narkoba. Ketika Islam lahir zat berbahaya yang paling popular memang baru minuman keras (khamr). Dalam perkembangan dunia Islam, khamr kemudian lazim disebut narkotika atau lebih luas lagi narkoba.

Disisi lain, narkotika merupakan obat atau bahan yang bermanfaat dibidang pengebotan, pelayanan kesehatan dan pengembangan ilmu pengetahuan, namun disisi lain dapat menimbulkan ketergantungan yang sangat merugikan tampa adanya pengendalian serta pengawasan yang ketat dan seksama. dalam hal ini apabila ditinjau oleh aspek yuridis maka keberadaan narkotika adalah sah. sesuai dengan UU Narkotika hanya melarang penggunaan narkotika tidak sesuai dengan ketentuan undang-undang. keadaan yang demikian ini dalam tataran empirisnya mengakibatkan obat yang mengandung zat adiktif dan narkotika sering disalah gunakan bukan untuk kepentingan ilmu pengetahuan dan pengobatan, melainkan dijadikan ajang bisnis yang menjanjikan dan berkembang pesat, yang mana kegiatan ini berimbas pada rusaknya fisik maupun psikis mental semua lapisan masyarakat.

\section{LANDASAN DASAR HUKUM}

\section{Firman Allah SWT}

a. Al- Qur'an Surat Annisa Ayat 43.

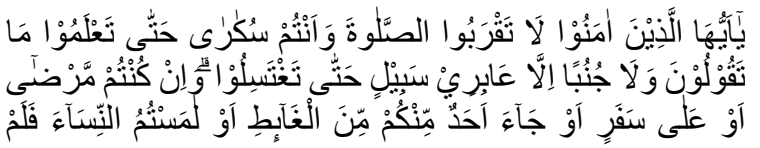

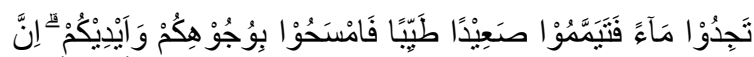

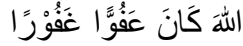

Artinya: Wahai orang-orang yang beriman, janganlah mendekati salat, sedangkan kamu dalam keadaan mabuk sampai kamu sadar akan apa yang kamu ucapkan dan jangan (pula menghampiri masjid ketika kamu) dalam keadaan junub, kecuali sekadar berlalu (saja) sehingga kamu mandi (junub). Jika kamu sakit, sedang dalam perjalanan, salah seorang di antara kamu kembali dari tempat buang air, atau kamu telah menyentuh perempuan, 156) sedangkan kamu tidak mendapati air, maka bertayamumlah kamu dengan debu yang baik (suci). Usaplah wajah dan tanganmu (dengan debu itu). Sesungguhnya Allah Maha Pemaaf lagi Maha Pengampun.

b. Al- Qur'an Surat al-maidah Ayat 90.

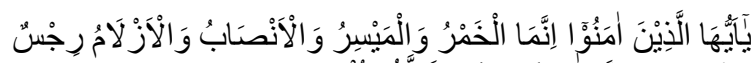

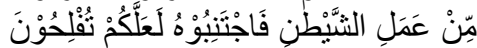
Artinya: Wahai orang-orang yang beriman, sesungguhnya minuman keras, berjudi, (berkurban untuk) berhala, dan mengundi nasib dengan anak panah adalah perbuatan keji (dan) termasuk perbuatan setan. Maka, jauhilah (perbuatan-perbuatan) itu agar kamu beruntung.

\section{Hadist Nabi SAW}

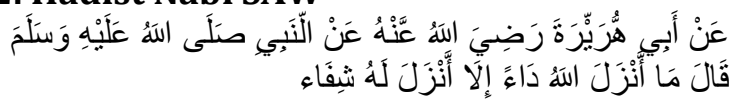

Artinya: Dari Abu Hurairah RA, dari Nabi SAW: Sesungguhnya Allah tidak menurunkan suatu penyakit kecuali menurunkan (pula) obatnya”. HR.Bukhari,

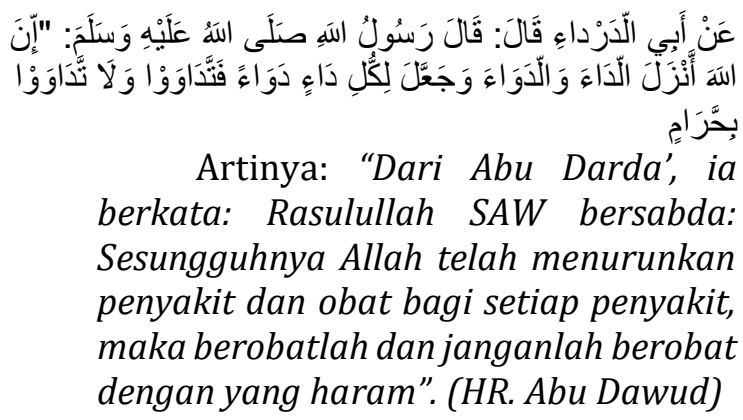

Artinya: "Dari Abu Darda', ia berkata: Rasulullah SAW bersabda: Sesungguhnya Allah telah menurunkan penyakit dan obat bagi setiap penyakit, maka berobatlah dan janganlah berobat dengan yang haram". (HR. Abu Dawud) 


\section{Fatwa Majelis Ulama Indonesia}

Fatwa Majelis Ulama Indonesia Nomor: 30 Tahun 2013 Tentang Obat Dan Pengobatan.

1. Obat yang digunakan untuk kepentingan pengobatan wajib menggunakan bahan yang suci dan halal.

2. Penggunaan bahan najis atau haram dalam obat-obatan hukumnya haram.

3. Penggunaan obat yang berbahan najis atau haram untuk pengobatan hukumnya haram kecuali memenuhi syarat sebagai berikut:

a) digunakan pada kondisi keterpaksaan (al-dlarurat), yaitu kondisi keterpaksaan yang apabila tidak dilakukan dapat mengancam jiwa manusia, atau kondisi keterdesakan yang setara dengan kondisi darurat (al-hajat allati tanzilu manzilah al-dlarurat), yaitu kondisi keterdesakan yang apabila tidak dilakukan maka akan dapat mengancam eksistensi jiwa manusia di kemudian hari.

b) belum ditemukan bahan yang halal dan suci.

c) adanya rekomendasi paramedis kompeten dan terpercaya bahwa tidak ada obat yang halal.

\section{PEMBAHASAN I}

\section{A. Jual Beli Dalam Islam}

Jual beli dalam bahasa Arab berasal dari kata (البيع) yang artinya menjual, mengganti dan menukar (sesuatu dengan sesuatu yang lain). Kata (البيع) dalam bahasa arab terkadang digunakan untuk pengertian lawannya, yaitu kata : الثر اء dengan demikian kata (البيع) berarti kata jual dan sekaligus berarti kata “beli".(M.Ali Hasan 2003)

Secara terminologi terdapat beberapa definisi para ulama diantaranya oleh ulama Hanafiyah memberi pengertian dengan 'saling menukarkan harta dengan harta melalui cara tertentu', atau dengan makna 'tukar menukar sesuatu yang diingini dengan sepadan melalui cara tertentu yang bermanfaat.
Ulama Hanafiyah menjelaskan bahwa makna khusus pada pengertian pertama tadi adalah ijab dan kabul, atau juga bisa melalui saling memberikan barang dan menetapkan harga antara pembeli dan penjual. Sedangkan pada pengertian kedua menjelaskan bahwa harta yang diperjualbelikan itu harus bermanfaat bagi manusia, seperti menjual bangkai, minuman keras dan darah tidak dibenarkan.(wahab alzuhaili 1989)

Sayid Sabiq mendefinisikan jual beli dengan arti 'saling menukar harta dengan harta atas dasar suka sama suka'. Sementara Imam al-Nawāwī menjelaskan bahwa jual beli adalah 'saling menukar harta dengan harta dalam bentuk pemindahan milik'. Defenisi ini tidak jauh berbeda dengan apa yang didefinisikan oleh Abū Qudāmah yaitu 'saling menukar harta dengan harta dalam bentuk pemindahan milik dan pemilikan'. Sementara menurut Hasbi ash-Shiddieqy jual beli adalah akad yang terdiri atas penukaran harta dengan harta lain, maka terjadilah penukaran dengan milik tetap. ( Hasbi Ash-Shiddieqy 1989)

Dari penjelasan beberapa ulama diatas, "hak milik dan pemilikan ditekankan", sebab ada tukar menukar harta yang sifatnya tidak harus dimiliki seperti sewa menyewa. Kata harta dalam beberapa pengertian di atas, terjadi perbedaan pendapat antara mazhab Hanafi dan jumhur ulama. Menurut jumhur ulama yang dimaksud harta adalah materi dan manfaat.

Oleh karena itu, manfaat dari suatu benda boleh diperjualbelikan. Sedangkan ulama mazhab Hanafi berpendapat, bahwa yang dimaksud dengan harta adalah sesuatu yang mempunyai nilai. Oleh sebab itu manfaat dan hak-hak, tidak dapat dijadikan objek jual beli. Adapun jual beli yang dimaksud dalam tulisan ini adalah transaksi yang mengandung dua unsur yaitu ijab dan qabul. 


\section{B. Rukun jual beli dalam Islam}

Rukun jual belli didalam islam ada empat, yaitu:

1. 'Aqid (subjek jual beli), yakni penjual dan pembeli.

2. Ma'qud 'alaih (Objek jual beli), yakni harga dan barang.

3. Mahal al-'Aqdi (shighat / pernyataan jual beli), yakni ijab dan qabul.

4. Maudhu 'al-' Aqdi (tujuan jual beli), yakni untuk saling memenuhi kebutuhan antar manusia.

\section{Syarat orang yang berakad}

Ulama fiqih sepakat, bahwa orang yang melakukan transaksi jual beli harus memenuhi syarat-syarat :

1. Berakal. Dengan syarat tersebut maka anak kecil yang belum berakal tidak boleh melakukan transaksi jual beli, dan jika telah terjadi transaksinya tidak sah. Jumhur ulama berpendapat, bahwa orang yang melakukan transaksi jual beli itu harus telah akil baliqh dan berakal. Apabila orang yang bertransaksi itu masih mumayyiz, maka transaksi jual beli itu tidak sah. Sekalipun mendapat izin dari walinya.

2. Orang yang melakukan transaksi itu, adalah orang yang berbeda. Maksud dari syarat tersebut adalah bahwa seorang tidak boleh menjadi pembeli dan penjual pada waktu yang bersamaan.

\section{Syarat yang terkait dengan ijāb dan qabūl.}

Ulama fiqih sepakat bahwa urusan utama dalam jual beli adalah kerelaan antara penjual dan pembeli. Kerelaan ini dapat terlihat pada saat transaksi berlangsung. Oleh karena itu, ijāb qabūl harus diungkapkan dengan jelas sehingga tidak terjadi penipuan dan dengan ijab Kabul dapat mengikat kedua belah pihak.

Apabila ijāb-qabūl telah diucapkan dalam transaksi, secara otamatis kepemilikan barang dan uang telah berpindah tangan. Ulama fiqih menjelaskan bahwa syarat dari ijābqabūl adalah sebagai berikut:
1. Jumhur ulama berpendapat bahwa orang yang mengucapkannya harus telah akil baligh dan berakal, sedangkan menurut Ulama Mazhab Hanafi mensyaratkan hanya telah berakal saja. Kabul harus sesuai dengan ijab.

2. Ijab dan Kabul harus dilakukan dalam satu transaksi, dan tidak boleh terpisah. Maksudnya kedua belah pihak yang melakukan transaksi harus hadir pada waktu yang bersamaan.

\section{E. Syarat yang diperjual belikan.}

Syarat yang diperjualbelikan, adalah sebagai berikut:

1. Barang itu ada, atau tidak ada ditempat, tetapi pihak penjual menyatakan sanggup untuk mengadakan barangitu

2. Barang tersebut dapat dimanfaatkan dan bermanfaat bagi manusia. Oleh karena itu keluar dari syarat ini adalah menjual khamar, bangkai haram untuk diperjualbelikan, karena tidak bermanfaat bagi manusia dalam pandangan syara'

3. Milik seseorang. Maksudnya adalah barang yang belum milik seseorang tidak boleh menjadi objek jual beli, seperti menjual ikan yang masih di laut, emas yang masih dalam tanah, karena keduanya belum menjadi milik penjual.

4. Dapat diserahkan pada saat akad berlangsung, atau pada waktu yang telah disepakati.

\section{F. Pengertian obat yang mengandung zat adiktif}

Obat adalah semua bahan tunggal atau campuran yang digunakan oleh semua makhluk untuk bagian dalam maupun bagian luar, guna mencegah, meringankan, maupun menyembuhkan penyakit (Syamsuni, 2007). Obat merupakan semua zat baik kimiawi, hewani, maupun nabati yang dalam dosis layak dapat menyembuhkan, meringankan, atau mencegah penyakit berikut gejalanya (Tjay dan Rahardja, 
2007).

Penggolongan obat berdasarkan
tingkat keamanan Pengertian
penggolongan obat yang menyatakan
bahwa penggolongan obat yang
dimaksudkan untuk peningkatan
keamanan dan ketepatan penggunaan
serta pengamanan distribusi. Pengertian
tersebut tercantum dalam Peraturan
Menteri Kesehatan RI Nomor
917/Menkes/Per/X/1993. Penggolongan
obat ini terdiri dari: obat bebas, obat bebas
terbatas, obat obat keras, obat golongan
narkotika, obat herbal terstandar (OHT)
dan obat herbal jamu.

\section{a. Obat Bebas}

Obat bebas ditandai dengan lingkaran berwarna hijau dengan garis tepi hitam. Ini menunjukkan bahwa obat tersebut dapat dibeli secara bebas tanpa menggunakan resep dokter. Di negara-negara Barat, obat ini disebut OTC atau over-the-counter. Ini adalah obat yang paling aman dan bisa dibeli bebas di warung, toko obat, maupun apotek.

Meskipun disebut aman, obat bebas tetap tidak boleh digunakan sembarangan. Karena bagaimanapun, obat memiliki kandungan kimia yang dapat berdampak pada tubuh.

Obat-obatan yang dapat dibeli secara bebas biasanya digunakan untuk mengatasi penyakit yang memiliki gejala ringan. Contohnya adalah parasetamol, vitamin, multivitamin, dan antasida.

\section{b. Obat Bebas Terbatas}

Obat jenis ini sebenarnya masih bisa dibeli tanpa resep dokter, namun tetap tergolong obat keras. Jadi bagi orang yang memiliki penyakit tertentu, penggunaan obat ini harus dilakukan dengan hati-hati dan sebaiknya menggunakan resep dokter.

Meski gejala dan keluhan penyakit sama, obat yang digunakan belum tentu sama. Obat ini ditandai dengan lingkaran biru bergaris tepi hitam.

Pengunaan obat ini pun harus mengikuti aturan pengobatan yang tertera pada kemasan. Jangan lupa perhatikan tanggal kedaluwarsa obat, serta membaca informasi pada kemasan tentang petunjuk penggunaan obat yang tidak diperbolehkan, efek samping, dosis obat, cara menyimpan obat, dan lainnya.Selain itu, terdapat 5 jenis obat bebas terbatas, yaitu:

1) P.No.1: Awas! Obat keras. Baca aturan pemakaiannya. P.No.2: Awas! Obat keras. Hanya untuk bagian luar dari badan. P.No.3: Awas! Obat keras. Tidak boleh ditelan. P.No.4: Awas! Obat keras. Hanya untuk dibakar. P.No.5: Awas! Obat keras. Obat wasir, jangan ditelan.

2) Beberapa obat yang dijual bebas terbatas adalah CTM, Theopiline, Tremenza, dan Lactobion.

\section{c. Obat Keras}

Obat keras hanya bisa didapatkan dengan resep dokter. Golongan obat ini ditandai dengan lingkaran merah dengan garis tepi berwarna hitam dan huruf $\mathrm{K}$ di tengah yang menyentuh garis tepi.

Obat-obatan yang termasuk dalam golongan ini, misalnya antibiotik, obat-obatan yang mengandung hormon, obat penenang, dan lain-lain. Contoh dari obat keras adalah asam mefenamat, loratadine, alprazolam, clobazam, pseudoefedrin.

Ketahuilah bahwa obat ini tidak bisa sembarang dikonsumsi, karena dapat berbahaya, meracuni tubuh, memperparah penyakit, atau menyebabkan kematian sehingga harus digunakan sesuai aturan yang tepat.

Obat bebas Obat golongan ini termasuk obat yang relatif paling aman, dapat diperoleh tanpa resep dokter, selain di apotek juga dapat diperoleh di warung-warung. Obat bebas dalam kemasannya ditandai dengan lingkaran berwarna hijau. Contohnya adalah parasetamol, vitamin c, asetosal (aspirin), antasida daftar obat esensial (DOEN), dan obat batuk hitam (OBH) (Priyanto, 2010).

\section{d. Obat Golongan Narkotik}

Ini merupakan golongan obat yang paling berbahaya. Obat golongan narkotik mempunyai simbol seperti tanda plus dengan lingkaran berwarna merah. 
Obat ini hanya bisa didapatkan dengan resep dokter, dengan tanda tangan dokter disertai nomor izin praktik dokter pada resep tersebut, dan tidak dapat menggunakan kopi resep.

Golongan obat narkotik berbahan dasar tanaman atau buatan berupa sintesis ataupun semi sintetis. Obat-obatan narkotik atau psikotropika dapat menimbulkan ketergantungan pada penggunanya, sehingga pemakaiannya perlu diawasi dengan ketat sesuai anjuran dan kebutuhan.

Selain itu, obat narkotik dapat memengaruhi susunan saraf pusat dan mempengaruhi tingkah laku serta aktivitas pada titik tertentu.

Mereka sering kali digunakan oleh dokter sebagai obat bius dan antinyeri atau analgetik potensi kuat. Karena itu, penggunaan obat ini hanya boleh dilakukan dengan dilakukan oleh dokter dan/atau dengan pengawasan dokter.

Dalam Undang-Undang No. 35 Tahun 2009 tentang Narkotika, narkotika golongan I hanya dapat digunakan untuk tujuan pengembangan ilmu pengetahuan dan tidak diperbolehkan digunakan untuk pelayanan kesehatan. Narkotika golongan II digunakan untuk pengobatan, akan tetapi hanya boleh digunakan dalam terapi (pengobatan) karena sifatnya yang berpotensi mengakibatkan ketergantungan bagi penggunanya dan untuk tujuan ilmu pengetahuan. Sedangkan narkotika golongan III mempunyai potensi ringan yang dapat menyebabkan ketergantungan. Dalam perkembangannya narkotika golongan III banyak digunakan dalam terapi dan pengobatan karena memiliki efek ringan yang ditimbulkan.

Berikut ini adalah contoh penerapan narkotika dalam pelayanan kesehatan/pengobatan:

1) LSD (Lysergic acid diethylamide), merupakan jenis narkotika yang terbuat dari sari jamur yang tumbuh di tanaman gandum hitam dan bijibijian. LSD ini berguna untuk mengobati ketergantungan, perawatan untuk depresi, dan meredakan sakit kepala. Dalam Spring Grove State Hospital di Maryland, para peneliti memberikan LSD kepada pasien kanker akut untuk melihat apakah dapat membantu mengurangi kecemasan. 1/3 dari pasien menyatakan bahwa ia berkurang rasa tegang, depresi, takut kematian dan kesakitannya (terbukti bahwa pereda nyeri efektif untuk sakit kronis). 1/3 lain menyatakan kondisinya cukup berkurang, dan kelompok terakhir menyatakan kondisi mereka tidak membaik sama sekali, tetapi juga tidak memburuk.

2) Jamur Psychedelic, dapat mengobati sakit kepala cluster dan OCD (Obsessive Compulsive Disorder). Suatu Studi University of Arizona menunjukan bahwa mereka dengan kondisi sakit kepala mereka, bisa reda sementara pada satu pasien, sakit kepalanya sembuh dan berlangsung selama 6 bulan penuh. Para peneliti mengakui studi ini tidak serta merta membuktikan bahwa obat itu dapat berfungsi sebagai pengobatan, mereka menyatakan ini berprospek untuk dilakukan studi lebih lanjut.

3) Ekstasi, dapat mengurangi kecemasan, meringankan gejala Parkinson"s dan perawatan untuk PTSD. Obat ini dapat mengobati penyakit Parkinson melalui pelepasan kadar seronin di otak, dan untuk korban PTSD (Post Traumatic Stress Disorder) juga menunjukan respons positif terhadap perawatan yang melibatkan ekstasi. Psikolog yang melakukan terapi menggunakan studi dan MDMA menemukan obat tersebut memberi mereka jendela waktu di mana pasien mengalami rasa takut sedikit tanggapan dan memadai bisa menangani terapi yang sangat pentng untuk bekerja melalui kondisi mereka.

4) Kokain dan Tanaman Coca, sebuah obat bius baru, obat pencahar dan 
sebagai obat motion sickness. Jauh sebelum bintang rock mulai melakukan mencandu kokain, kokain pernah secara luas dipuji sebagai obat ajaib yang dapat digunakan untuk menyembuhkan segala sesuatu mulai dari rasa sakit kepala dan alkoholisme untuk demam akut. Sedangkan daun koka dapat mengobati mabuk perjalanan, radang tenggorokan, sembelit, dan obesitas.

5) Heroin, digunakan sebagai salah satu perawatan paling efektif dan paling aman untuk sakit kronis yang ekstrim, seperti penderitaan yang dialami pasien kanker.

\section{e. Obat Fitofarmaka}

Obat golongan ini memiliki tanda kristal salju berwarna hijau pada lingkaran kuning dengan tepi warna hijau.

Perbedaannya dari obat herbal biasa terletak pada proses pengolahan bahan herbal yang telah ditunjang oleh bukti ilmiah secara penelitian klinik (sampai ke manusia), sehingga dapat disetarakan dengan obat modern.

Penelitian klinik akan lebih meyakinkan para dokter untuk mempergunakan obat ini karena telah terbukti, sehingga dapat disetarakan dengan obat-obat modern lainnya.

\section{f. Obat Herbal Terstandar (OHT)}

Golongan obat ini ditandai dengan simbol lingkaran kuning dengan garis tepi hijau dan gambar tiga buah bintang hijau di dalamnya.

Obat ini merupakan obat yang diekstrak dari bahan alam seperti dari tanaman, hewan, maupun mineral. Umumnya obat ini telah ditunjang dengan bukti ilmiah, yaitu secara penelitian pre-klinik, uji toksisitas dan dibutuhkan proses rumit, keterampilan dan teknologi tinggi

\section{g. Obat Herbal (Jamu)}

Kemasan obat herbal dilabeli dengan gambar logo tumbuhan atau pohon berwarna hijau dengan lingkaran hijau. Bahan dasar dari obat herbal terbuat dari seluruh bagian tanaman yang telah diolah untuk mendapatkan khasiatnya sesuai dengan prosedur keamanan.

Zat adiktif adalah obat serta bahan-bahan aktif yang apabila dikonsumsi oleh organisme hidup, maka dapat menyebabkan kerja biologi serta menimbulkan ketergantungan atau adiksi yang sulit dihentikan dan berefek ingin menggunakannya secara terus-menerus. Jika dihentikan dapat memberi efek lelah luar biasa atau rasa sakit luar biasa. Zat yang bukan tergolong narkotika dan psikotropika tetapi menimbulkan ketagihan antara lain kopi, rokok, minuman keras, dll.

Perkembangan ilmu pengetahuan dan semakin majunya teknologi membawa manusia kedalam dimensi baru. Pergaulan dan gaya hidup bebas membentuk suatu budaya baru terutama dikalangan generasi muda sehingga Narkotika dijadikan sebagai bahan percobaan. Narkotika memang mempunyai kegunaan tetapi mudhoratnya lebih besar di bandingkan dengan kegunaannya.

Kegunaan Narkotika dalam dunia kedokteran sangatlah bermanfaat terutama dalam dunia bedah. Tetapi dampak yang ditimbulkan akibat mengonsumsi dan menyalahgunakan Narkoba sangatlah besar seperti hilangnya kesadaran, bergembira yang berlebihan, menghilangkan rasa takut dan menjadikan seseorang percaya diri.

\section{G. Dampak Narkotika Dalam Kesehatan.}

Dampak bagi kesehatan bila mengonsumsi Narkoba adalah Paranoid (rasa takut yang tinggi), daya tahan tubuh menurun serta yang sangat buruk yaitu terjangkit penyakit AIDS. Setiap orang harus tetap waspada dalam menjaga kesehatan agar tubuh tetap memiliki imun yang kuat serta menjauhi dan tidak menyalahgunakan Narkoba.

Disisi lain, dalam mengonsumsi Narkoba tubuh akan melemah dan kemungkinan besar akan berakibat fatal seperti kecelakaan, abnormal bahkan berujung pada kematian. Jika mengonsumsi zat atau benda ini maka akan berpengaruh pada kinerja otak dan dapat menimbulkan 
ketergantungan.(Amar Mar'ruf. 2018)

\section{PEMBAHASAN II}

Jual Beli Obat Yang Mengandung Zat Adiktif Prespektif Hukum Ekonomi Syariah.

zat adiktif dan Narkotika atau obat-obat terlarang (Narkoba) dalam bahasa Arab yaitu al- mukhaddirat yang berarti membius, tidak sadar, mati rasa, atau memabukkan. Sedangkan menurut istilah Narkoba tidak disebutkan secara jelas dalam al-Quran maupun didalam Hadis tetapi hanya menjelaskan tentang Khamar, tetapi hal dapat ditentukan status hukumnya melalui metode Qiyas. Qiyas adalah menyamakan atau membandingkan suatu hukum yang dimana dilihat dari besarnya dampak yang di timbulkan dengan kebaikan yang diberikan. Dilihat dari segi dampak buruk yang diberikan, Narkoba memiliki dampak buruk yang lebih besar dibandingkan dengan khamar Dalam hukum Islam Narkotika tergolong kedalam khamar karena benda ini dapat memabukkan dan menghilangkan akal pikiran yang disebabkan oleh 'Illat yang ditimbulkannya. 'Illat merupakan salah satu benda yang dapat memabukkan sesuai dengan Hadis Nabi :

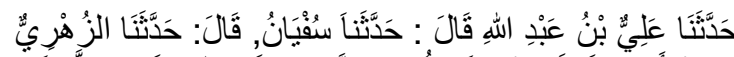

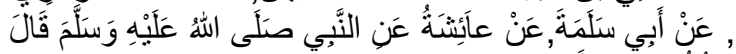

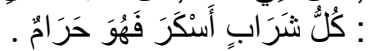

Artinya : telah menceritakan kepada kami 'Ali bin 'Abdillah, dia berkata: telah menceritakan kepada kami Sufyan, dia berkata: telah menceritakan kepada kami zuhri, dari Abu Salamah, Dari 'Aisyah, dari Rasulullah saw. bersabda: Setiap yang memabukkan itu khamar dan setiap khamar itu haram:

Disamping diharamkannya Narkotika atau obat-obat terlarang (Narkoba), bagi orang yang pernah merasakan kenimatan dapat menimbulkan ketagihan, serta dapat berakibat buruk dan dapat merusak akal dan fisik. Ibn Taimiyah menerangkan bahwa Ganja lebih di yakini lebih jahat dari khamar, maka dari itu hukum Islam melarang menggunakan maupun mengonsumsi benda-benda yang seperti ini baik dalam jumlah sedikit maupun banyak.

Selain itu, Sayyid Al-Sabiq berpendapat, , Sesungguhnya Ganja itu haram. Ganja itu lebih keji dibandingkan dengan khamar. Orang yang menyalahgunakannya akan diberikan sanksi had, sebagaimana dengan sanksi peminum khamar. Ganja bukan hanya merusak akal tetapi dapat menyebabkan seseorang berpaling dan tidak mengingat Allah dan melaksanakan Sholat. Jika ditinjau dari segi sifatnya Ganja memiliki sejuta dampak negatif kepada tubuh maka dari itu Ganja secara lafal dan maknawi telah diharamkan oleh Allah swt dan Rasulnya dan termasuk kedalam kategori haram. Imam Abu Habifah berpendapat bahwa minum arak adalah haram baik dari mana datangnya arak tersebut. Sedangkan dari penyalahgunaan Narkoba dikatakan haram apabila ia memabukkan dan memberi iqab keatasnya. Imam Malik berpendapat pengharaman arak dalam Islam ialah pengharaman Narkoba secara itlaq baik ia dinamakan arak atau bukan arak, apabila ia memabukkan maka hukumnya adalah haram. Pendapat ini adalah sama juga dengan dua imam lagi yaitu dari mazhab Syafi'e dan Ahmad.

Di antara pendapat Imam Malik dalam hal miras adalah : Pertama, semua yang memabukkan tidak boleh dikonsumsi walaupun dalam kondisi darurat. Kedua, dalam kitab Mudawwanah juz X hlm 365, Imam Malik mengatakan, seorang Nasrani

harus dicambuk kalau menjual khamar kepada Muslim jika tahu pembelinya adalah Muslim.

Pandangan yang sama yaitu dari Dr. Ahmad Fathie Bahnasie yang mengemukakan bahwa dalam menentukan suatu hukum Narkoba serta perkara yang memabukkan itu merupakan haram berdasarkan nas al-Quran dan Hadis Rasulullah. Hukuman terhadap penyalahguna Narkoba kiranya di kenakan hukum ta'zir karena Narkoba merupakan jalan menuju kemungkaran dan kemusnahan.(Hamzah 2012)

Hikmah diharamkannya khamar dikarenakan zat ini adalah induk kejahatan serta dapat membuat seseorang melakukan tindak kejahatan. Ulama telah sepakat menjadikan Narkoba hukumnya haram baik itu kepada pemakai, bandar, pengedar sekalipun petani yang menanam tanaman yang dapat di jadikan Narkoba. 
Bedasarkan rukun dan syarat jual beli dalam transaksi jual beli obat yang mengandung zat adiktif dan narkotika ini. Yang menjadi permasalahanya adalah subjek barang yang dijual yaitu obat yang memilikiki kandungan yang memabukkan bila dikonsumsi. Lain halnya transaksaksi jual beli obat ini digunakan sebagai saran penelitian atau pun pengobatan ulama sepakat sah-sah saja selagi tidak ada obat lain selain obat yang mengandung zat adiktif tersebut. jika sudah ada obat yang dapat menggatikannya maka mutlak jual beli obat yang menggunakan zatadiktif dan narkotika hukumnya haram. penyalahgunaan obat yang mengandung zat adiktif jika diliat dari sudut pandang etika bisnis islam penjual tidak semestinya menjual kesembarang orang tampa ada unsur pengobatan ataupun penelitian kepada pembeli, yang pelu diperhatikan bisnis dalam islam bukan hanya sekedar dengan meraih keuntungan semata melaikan perlu ditinjau dari aspek mudharat dan mafsadat bagi kedua belah bihak yang bertransaksi.

\section{TAWARAN PENULIS}

Dari pembahasan diatas penulis sependapat dengan pendapat ulama dengan mengharamkan khamar. dan penulis pun sepakat dengan Fatwa Majelis Ulama Indonesia Nomor: 30 Tahun 2013 Tentang Obat Dan Pengobatan, Penggunaan obat yang berbahan najis atau haram untuk pengobatan hukumnya haram kecuali memenuhi syarat sebagai berikut:

1. digunakan pada kondisi keterpaksaan (aldlarurat), yaitu kondisi keterpaksaan yang apabila tidak dilakukan dapat mengancam jiwa manusia, atau kondisi keterdesakan yang setara dengan kondisi darurat (alhajat allati tanzilu manzilah al-dlarurat), yaitu kondisi keterdesakan yang apabila tidak dilakukan maka akan dapat mengancam eksistensi jiwa manusia di kemudian hari.

2. belum ditemukan bahan yang halal dan suci.

3. adanya rekomendasi paramedis kompeten dan terpercaya bahwa tidak ada obat yang halal.

\section{KESIMPULAN DAN SARAN}

Dari beberapa pemaparan diatas penulis menarik kesimpulan bahwa segala sesuatu yang sifatna memabukkan itu haram. jual beli obat yang mengandung zat Adiktifdan narkotika untuk saat ini masih diperbolehkan sampai ada obat yang suci tampa mengandung unsur narkotika didalmnya yang menggatikan. jual beli obat yang mengandung zat adiktif dan narkotika haram hukum transaksaksinya jika hanya dijadikan sebagai sarana bisnis untuk meraih keuntungan semanta tampa melihat prihal kebutuhan konsumennya. dalam hal ini jual beli obat yang mengandung zat adiktif dan narkotika hanya boleh dijual belikan sebagai sarana pengobatan dan sarana penelitian.

Penulis menyarankan kepada setiap pelaku transaksi jual beli obat yang mengandung zat adiktif dan narkotika agar mematuhi peketetapan yang ada. dan semoga apa yang penulis paparkan dapat menjadi acuan untuk peneliti selanjutnya.

\section{DAFTAR PUSTAKA}

Ali Hasan, Muhammad. (2003). Berbagai Macam Transaksi dalam Islam, Fiqih Muamalah. Jakarta: PT Raja Grafindo Persada

Alifia, Ummu. (2020). Apa Itu Narkotika dan Napza?. Semarang: Alprin.

As-Sayyid, Sabiq. (1995M/1410H. Fiqh assunnah, Madinah: Dar Al-Fath.

Esther, J., \& Manullang, H. (2021). Aspek Hukum Pidana Dampak Penyalahgunaan Narkotika Bagi Remaja. Jurnal Ilmiah Pengabdian Kepada Masyarakat, 2(2), 10-23

Hasan, Hamzah. (2012), Al-Daulah : Jurnal Hukum Pidana dan Ketatanegaraan', Ancaman Pidana Islam Terhadap Penyalahgunaan Narkoba, vol.1 no. 1.

Maruf, Amar. (2018). "Pendekatan Studi Islam Dalam Rehabilitasi Penyalahguna Narkoba". Jurnal Tawadhu. Vol. 2 No. 1.

Priyanto., (2009), Farmakoterapi dan Terminologi Medis, 39, Lembaga Studi dan Konsultasi Farmakologi (Leskonfi), Depok Jabar.

Tjay, Tan Hoan dan Kirana Rahardja, (2007), Obat-Obat Penting Khasiat, Penggunaan dan Efek-Efek Sampingnya, Edisi Keenam, 262, 269271, PT. Elex Media Komputindo, Jakarta. 